$\mathrm{A} \int_{\text {ars }} \mathrm{H}$

Article history :

Received : 18.06.2015

Revised : 19.10 .2015

Accepted : 06.11.2015
THEASIAN JOURNALOF HORTICULTURE

Volume 10 | Issue 2 | December, 2015 | 201-206

Visit us -www.researchjournal.co.in

RESEARCH PAPER

DOI : 10.15740/HAS/TAJH/10.2/201-206

\title{
Heterosis for yield and its components in okra [Abelmoschus esculentus (L.) Moench]
}

\section{J.N. TIWARI ${ }^{1}$, SANJEEV KUMAR, T.R. AHLAWAT ${ }^{2}$, AKHILESH KUMAR $^{1}$ AND NISHTHA PATEL ${ }^{1}$}

ABSTRACT : The present investigation was carried out to study heterosis for various horticultural traits of okra in late Kharif- 2013 and summer, 2014 by involving five diverse parents in a diallel mating including reciprocals. The analysis of variance reflected considerable variability for yield and other component traits. VRO-6 was excellent over other parents in per se performance for majority of traits under investigation except average fruit weight, fruit stalk length and ascorbic acid. The cross-combination VRO-6 x GJO-3 was the only $\mathrm{F}_{1}$ exhibiting significant heterobeltiosis as well as standard heterosis for yield per plant. Whereas hybrids AA x AOL-12-52, AA x GJO-3 and VRO-6 x AA also displayed significant heterosis over better parent for this character. The cross-combination VRO-6 x GJO-3 also recorded significant and desirable heterotic gain over standard check for other traits like first flowering node, days to first flowering, number of branches per plant and average fruit weight.

KEY WORDS : Heterosis, Okra, Per se performance, Diallel, Horticultural traits

HOW TO CITE THIS ARTICLE : Tiwari, J.N., Kumar, Sanjeev, Ahlawat, T.R., Kumar, Akhilesh and Patel, Nishtha (2015). Heterosis for yield and its components in okra [Abelmoschus esculentus (L.) Moench]. Asian J. Hort., 10(2) : 201-206. 